\title{
APOBEC3G Gene
}

National Cancer Institute

\section{Source}

National Cancer Institute. APOBEC3G Gene. NCI Thesaurus. Code C68588.

This gene may play a role in cell growth and the cell cycle. 